\title{
Hubungan antara kadar procalcitonin dengan kriteria Anthonisen pada PPOK eksaserbasi akut
}

\author{
Ariska Megasari ${ }^{1 *}$, Ida Bagus Ngurah Rai ${ }^{2}$, Ketut Suryana ${ }^{2}$
}

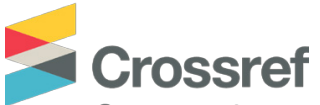

Crossmark

DOI : 10.36216/jpd.v3i1.38
${ }^{1}$ Program Studi Pendidikan Dokter Spesialis Penyakit Dalam, Fakultas Kedokteran Universitas Udayana/RSUP Sanglah, Denpasar, Bali, Indonesia ${ }^{2}$ Departemen/KSM Penyakit Dalam, Fakultas Kedokteran Universitas Udayana/RSUP Sanglah, Denpasar, Bali Indonesia

*Korespodensi : Ariska Megasari Program Studi Pendidikan Dokter Spesialis Penyakit Dalam, Fakultas Kedokteran Universitas Udayana/RSUP Sanglah, Denpasar, Bali, Indonesia riska_megasari@yahoo.com

Diterima: 4 Januari 2019; Disetujui: 28 Januari 2019; Diterbitkan: 15 Februari 2019
Latar belakang: PPOK eksaserbasi dapat disebabkan oleh infeksi (virus dan bakteri) dan faktor polutan lingkungan. Salah satu pedoman pemberian antibiotik pada PPOK eksaserbasi akut adalah pada penderita dengan kriteria Anthonisen tipe 1 dan 2 yang berdasarkan keluhan subjektif pasien (peningkatan sesak, peningkatan volume sputum dan purulensi sputum). Procalcitonin (PCT) merupakan marker objektif infeksi spesifik bakteri.

Tujuan: Penelitian ini dilakukan untuk mengetahui hubungan antara kadar procalcitonin dengan kriteria Anthonisen pada PPOK eksaserbasi akut.

Metode: Penelitian ini menggunakan rancangan cross sectional analitik pada penderita PPOK eksaserbasi akut yang berobat ke RSUP Sanglah dan RSUD Wangaya pada bulan Maret-Mei 2018. Analisis data menggunakan uji korelasi bivariat Spearman, serta Kruskal-wallis untuk mengetahui perbedaan median PCT pada tipe Anthonisen.

Hasil: Hasil dari 43 sampel penderita PPOK eksaserbasi akut didapatkan median kadar PCT 0,18 $(0,02-47,8) \mathrm{ng} / \mathrm{ml}$. Pada analisis korelasi Spearman tidak ditemukan korelasi bermakna antara kadar PCT serum dengan tipe Anthonisen $(r=-0,175, p=0.26)$. Setelah mengeksklusi beberapa data outlier, terdapat perbedaan median $P C T$ yang signifikan berdasarkan tipe Anthonisen.yaitu median PCT lebih tinggi pada Anthonisen tipe 1 dibanding tipe 2 dan 3 ( $p=0,029)$. Hal ini menandakan bahwa penderita dengan 3 gejala kardinal (eksaserbasi berat) kemungkinan infeksi bakteri sebagai pencetus eksaserbasi lebih besar dibandingkan derajat ringan dan sedang.

Simpulan: Tidak terdapat hubungan antara kadar PCT dengan tipe Anthonisen pada PPOK eksaserbasi akut namun kami mendapatkan nilai PCT lebih tinggi signifikan pada Anthonisen tipe 1 setelah mengekslusi nilai ekstrim.

Kata Kunci: Procalcitonin (PCT), kriteria Anthonisen, PPOK eksaserbasi akut

Background: COPD exacerbations can be caused by viruses, bacteria and environmental pollutants. One guideline for antibiotic administration is in patients with Anthonisen criteria types 1 and 2 based on patients' subjective complaints (increased dyspneu, increased sputum volume and sputum purulence). Procalcitonin (PCT) is an objective and specific marker of bacterial infections.

Objective: This study was conducted to determine the relationship between procalcitonin levels and Anthonisen criteria in acute exacerbation of COPD.

Method: This study used an analytical cross sectional design on acute exacerbation COPD patients at Sanglah General Hospital and Wangaya Hospital in March-May 2018. Data analysis used the Bivariate Spearman correlation test, and Kruskal-wallis to determine the median PCT level difference according to Anthonisen type.

Results: Total subjects were 43 samples of acute exacerbation COPD patients, with median PCT levels were $0.18(0.02$ 47.8) $\mathrm{ng} / \mathrm{ml}$. We found no significant correlation between serum PCT levels and Anthonisen type $(r=-0,175, p=0.26)$. After excluding several outliers data, there was a significant difference in median PCT value based on the Anthonisen type. The median PCT was higher in Anthonisen type 1 compared to type 2 and $3(p=0.029)$. This indicates that patients with 3 cardinal symptoms (severe exacerbation) are more likely to have bacterial infection.

Conclusion: There was no relationship between levels of PCT with Anthonisen type in acute COPD exacerbations but we found significant higher PCT level in Anthonisen type 1 after excluding extreme value.

Keywords: Procalcitonin (PCT), Anthonisen criteria, acute exacerbation COPD 


\section{PENDAHULUAN}

Penyakit Paru Obstruktif Kronis (PPOK) eksaserbasi didefinisikan sebagai kondisi akut yang ditandai perburukan gejala respirasi dibandingkan variasi normal sehari-hari sehingga membutuhkan perubahan terapi. ${ }^{1,2}$ PPOK eksaserbasi menurunkan kualitas hidup, mempercepat progresivitas penyakit dan meningkatkan risiko kematian. ${ }^{1}$ Angka kematian di rumahsakit pada pasien PPOK eksaserbasi akut berkisar antara $4 \%-30 \%{ }^{3}$

Eksaserbasi pada PPOK paling sering dicetuskan oleh infeksi bakteri atau virus, namun juga bisa karena polusi lingkungan, gagal jantung, emboli paru, dan ketidakpatuhan pengobatan. ${ }^{1}$ Standar baku diagnosis kausa bakterial adalah dengan isolasi bakteri patogen pada kultur sputum, namun kultur sputum tidak spesifik maupun sensitif. Spesifisitas kultur sputum rendah dikarenakan bisa didapatkannya kuman kontaminasi. Kesulitan lain adalah sejumlah signifikan pasien dengan PPOK stabil juga mempunyai kolonisasi bakteri yang termasuk organisme yang sering berhubungan dengan eksaserbasi. ${ }^{1}$ Pemeriksaan kultur sputum juga membutuhkan waktu yang lama (sekitar 1 minggu) sehingga memperlambat diagnosis. Pemeriksaan lain tidak bisa dikerjakan rutin karena invasif seperti pemeriksaan bronchoalveolar lavage (BAL).

Pedoman dari Global Initiative for Chronic Obstructive Lung Disease (GOLD) merekomendasikan antibiotik dalam pengobatan eksaserbasi akut PPOK sedang sampai berat menurut gejala kardinal kriteria Anthonisen. Kriteria Anthonisen terdiri dari laporan pasien mengenai gejala kardinal yaitu peningkatan sesak, volume sputum, dan purulensi sputum. ${ }^{2}$ Studi ini berdasarkan populasi pasien rawat jalan dimana pemeriksaan mikrobiologi sputum tidak dilakukan sehingga kausa bakteri eksaserbasi tidak dikonfirmasi. ${ }^{4}$

Procalcitonin (PCT) saat ini mendapat perhatian yang cukup besar sebagai penanda infeksi bakterial yang lebih spesifik. Procalcitonin banyak dihasilkan oleh tubuh sebagai respon terhadap endotoksin atau mediator inflamasi yang dilepaskan oleh infeksi bakterial. Procalcitonin berkorelasi dengan luas dan keparahan infeksi bacterial. ${ }^{5}$ Procalcitonin mempunyai sensitivitas dan spesifisitas yang tinggi dalam mendiagnosis infeksi bakteri. ${ }^{6}$

Meskipun banyak studi menunjukkan efikasi marginal terapi antibiotika pada PPOK, 85\% pasien dengan PPOK eksaserbasi akut diterapi dengan antibiotika. Penggunaan antibiotika yang salah dapat merugikan pasien disebabkan efek samping pengobatan dan dari segi populasi secara umum disebabkan munculnya resistensi antibiotika. ${ }^{7}$

Meskipun keunggulan karena kesederhanaan penggunaan kriteria Anthonisen dalam keputusan antibiotika serta bisa dikerjakan di semua fasilitas kesehatan, kriteria ini berdasarkan gejala saja/ bersifat sukjektif. Studi mengenai validitas kriteria Anthonisen sebagai prediktor infeksi bakteri pada PPOK eksaserbasi akut di Indonesia, tidak banyak dilakukan. Atas dasar pertimbangan tersebut maka peneliti ingin mengetahui apakah kriteria Anthonisen sebagai panduan pemberian antibiotik yang sederhana berhubungan dengan kadar procalcitonin sebagai marker spesifik infeksi bakteri pada pasien PPOK eksaserbasi akut.

\section{BAHAN DAN METODE}

\section{Desain Penelitian}

Penelitian ini adalah penelitian studi potong lintang analitik untuk mengetahui hubungan antara kadar procalcitonin dengan kriteria Anthonisen pada pasien PPOK eksaserbasi akut. Kriteria inklusi adalah semua pasien dengan diagnosa klinis PPOK eksaserbasi akut yang berobat di RSUP Sanglah dan RSUD Wangaya dalam bulan Maret-Mei 2018. Kriteria eksklusi diantaranya Pasien PPOK yang disertai kondisi komorbid berat (syok, trauma pembedahan, luka bakar, pankreatitis berat, penyakit hati berat, disfungsi multi organ), diduga infeksi malaria, infeksi fungi, penggunaan agen yang merangsang sitokin (anti limfosit globulin, alemtuzumab, IL-2, tranfusi granulosit), sindrom paraneoplastik terkait kanker tiroid medullary dan karsinoma paru sel kecil, penyakit vaskulitis autoimun dan graft versus host disease, penggunaan antibiotika sebelumnya, dan bukti infeksi di tempat lain selain paru.

Kadar serum procalcitonin diukur dengan menggunakan alat COBAS Elecsys B.R.A.H.M.S PCT ${ }^{\mathrm{TM}}$ yang menggunakan metode ECLIA (Electrochemiluminescence immunoassay). Pengambilan serum sebanyak $3 \mathrm{ml}$, dilakukan segera setelah diagnosa PPOK eksaserbasi akut ditegakkan dan sebelum mendapat antibiotika. Nilai normal procalcitonin adalah $<0,1 \mathrm{ng} / \mathrm{mL}^{6}$ dan pengerjaannya di laboratorium RSUP Sanglah Denpasar.

\section{Analisis Statistik}

Analisis Univariat dalam penelitian ini meliputi hasil secara deskriptif untuk memperoleh karakteristik sunjek penelitian dengan menggunakan tabel distribusi frekuensi, mean, standar deviasi, nilai maksimum dan nilai minimum, serta uji normalitas data. Uji normalitas yang digunakan adalah saphiro wilk.

Analisis bivariat yang digunakan adalah menggunakan Spearman rank correlation. Selain analisis korelasi, juga penting ditampilkan perbandingan rerata kadar proklasitonin beradasarkan derajat eksaserbasi menurut kriteria Anthonisen. Berdasarkan kepentingan tersebut dilakukan uji one-way anova jika sebaran data berdistribusi normal. Jika data tidak berdistribusi normal, digunakan uji Kruskal Wallis. Tingkat kemaknaan menggunakan a 0,05 dimana a $<0,05$ menyatakan 
ada perbedaan dan $a \geq 0,05$ yang menyatakan tidak ada perbedaan antara variabel bebas dan tergantung.

\section{HASIL}

Penelitian ini melibatkan 43 penderita eksaserbasi akut yang datang ke UGD Rumah Sakit Umum Sanglah Denpasar dan Wangaya pada bulan Maret sampai Mei 2018. Dari 43 penderita yang mengikuti penelitian, 21 orang $(48,8 \%)$ berjenis kelamin laki-laki dan 22 orang $(51,2 \%)$ berjenis kelamin perempuan. Berdasarkan faktor risiko paparan merokok, lebih dari setengah sampel merupakan perokok $(58,1 \%)$. Berdasarkan risiko terjadinya eksaserbasi, sebagian besar termasuk dalam kategori risiko tinggi ( 32 eksaserbasi per tahun atau $>1$ eksaserbasi yang memerlukan rawat inap dalam 1 tahun) yaitu $86 \%$.

Gejala eksaserbasi yaitu peningkatan sesak didapatkan sebanyak 90,7\%, peningkatan volume sputum yaitu $60,5 \%$ dan peningkatan purulensi sputum yaitu 41,9\%. Secara ringkas, derajat eksaserbasi yang dinilai dengan kriteria anthonisen, 32,6\% adalah derajat berat (Anthonisen tipe 1), 27,9\% derajat sedang (Anthonisen tipe 2), dan 39,5\% derajat ringan (Anthonisen tipe 3). Penderita PPOK eksaserbasi akut yang disertai dengan infiltrate pada pemeriksaan rontgen dada sebanyak 48,8\% dan sisanya tidak didapatkan infiltrat. Pemeriksaan kultur sputum dikerjakan pada 23,2\% sampel dengan hasil berupa flora normal regional dan pemeriksaan kultur darah dikerjakan pada 14\% sampel dengan hasil tidak ada pertumbuhan kuman.

Karakteristik umur, nadi, dan white blood cell (WBC) pada sampel berdistribusi normal yaitu $\mathrm{p}>0,05$ pada uji saphirowilk, maka digunakan mean sebagai ukuran pemusatan dan standar deviasi (SD) sebagai ukuran penyebaran. Nilai rerata masing-masing data didapatkan: umur 72,26 \pm 9,6 tahun; nadi $99,58 \pm 21,2 \mathrm{kali} / \mathrm{menit}$ dan WBC 13,2 $\pm 5,52 \times 10^{3} / \mathrm{ml}$. Data mean arterial pressure (MAP), laju respirasi, temperatur, hitung neutrofil, procalcitonin dan saturasi oksigen yang didapatkan pada subjek penelitian terdistribusi tidak normal yaitu $\mathrm{p}<$ 0,05 pada uji Saphiro-wilk. Median dari masing-masing data didapatkan: MAP 96,67 (70-146,7) $\mathrm{mmHg}$; laju respirasi 24 (16-44) kali/menit, temperatur $36,8(35,8-39,4){ }^{\circ} \mathrm{C}$; hitung neutrofil 10,29 $(3,0-25,83) 10^{3} / \mathrm{ml}$; procalcitonin $0,18(0,02$ - 47,8) ng/ml; saturasi oksigen 98 (72-99) \%.

Setelah dilakukan analisis korelasi dengan uji korelasi Spearman, tidak ditemukan korelasi yang signifikan antara kadar procalcitonin dan tipe Anthonisen dengan koefisien korelasi sebesar - 0,175 dan nilai signifikansi $\mathrm{p}=0,26$ (> $0,05)$. Untuk mengetahui sebaran data, pada SPSS dilakukan explore terhadap data dengan menggunakan boxplot yang mendapatkan beberapa outliers. Sehingga pada penelitian ini tidak bisa dilakukan uji korelasi dikarenakan beberapa outlier yang akan mengganggu hasil analisa uji korelasi dengan
Tabel 1. Karakteristik sampel

\begin{tabular}{|c|c|}
\hline Karakteristik & Hasil \\
\hline \multicolumn{2}{|l|}{ Jenis kelamin, $\mathbf{n}(\%)$} \\
\hline Laki-Laki & $21(48,8 \%)$ \\
\hline Perempuan & $22(51,2 \%)$ \\
\hline \multicolumn{2}{|l|}{ Status merokok, n (\%) } \\
\hline Perokok & $25(58,1 \%)$ \\
\hline Bukan Perokok & $18(41,9 \%)$ \\
\hline \multicolumn{2}{|l|}{ Risiko eksaserbasi, n (\%) } \\
\hline Risiko rendah & $6(14 \%)$ \\
\hline Risiko tinggi & $37(86 \%)$ \\
\hline \multicolumn{2}{|l|}{ Gejala kardinal eksaserbasi, n (\%) } \\
\hline Peningkatan sesak & $39(90,7 \%)$ \\
\hline Peningkatan volume sputum & $26(60,5 \%)$ \\
\hline Peningkatan purulensi sputum & $18(41,9 \%)$ \\
\hline \multicolumn{2}{|l|}{ Tipe Anthonisen, $\mathbf{n}(\%)$} \\
\hline Tipe 1 (derajat berat) & $14(32,6 \%)$ \\
\hline Tipe 2 (derajat sedang) & $12(27,9 \%)$ \\
\hline Tipe 3 (derajat ringan) & $17(39,5 \%)$ \\
\hline \multicolumn{2}{|l|}{ Rontgen dada, n (\%) } \\
\hline Ada infiltrat & $21(48,8 \%)$ \\
\hline Tidak ada infiltrat & $22(51,2 \%)$ \\
\hline \multicolumn{2}{|l|}{ Komorbid, n (\%) } \\
\hline IHD & $10(23,3 \%)$ \\
\hline Hipertensi & $17(39,5 \%)$ \\
\hline Atrial fibrilasi & $6(14 \%)$ \\
\hline Gagal Jantung & $19(44,2 \%)$ \\
\hline $\mathrm{DM}$ & $3(7 \%)$ \\
\hline Bronkiektasis & $4(9,3 \%)$ \\
\hline Umur (tahun), rerata \pm SD & $72,26 \pm 9,6$ \\
\hline Nadi (kali/menit), rerata \pm SD & $99,5 \pm 21,2$ \\
\hline $\begin{array}{l}\text { Temperatur (Celcius), median } \\
\text { (minimum-maksimum) }\end{array}$ & $36,6(35,8-39,4)$ \\
\hline $\begin{array}{l}\text { Respirasi (kali/menit), median } \\
\text { (minimum-maksimum) }\end{array}$ & $24(16-44)$ \\
\hline $\begin{array}{l}\text { MAP (mmHg), median (minimum- } \\
\text { maksimum) }\end{array}$ & $96,67(70-146,7)$ \\
\hline WBC $\left(10^{3} / \mathrm{ml}\right)$, rerata \pm SD & $13,2 \pm 5,52$ \\
\hline $\begin{array}{l}\text { Hitung neutrofil }\left(10^{3} / \mathrm{ml}\right) \text {, median } \\
\text { (minimum-maksimum) }\end{array}$ & $10,29(3,0-25,83)$ \\
\hline $\begin{array}{l}\text { Procalcitonin (ng/ml), median } \\
\text { (minimum-maksimum) }\end{array}$ & $0,18(0,02-47,8)$ \\
\hline $\begin{array}{l}\text { Saturasi oksigen (\%),median } \\
\text { (minimum-maksimum) }\end{array}$ & $98,0(72-99)$ \\
\hline
\end{tabular}

SD: Standar deviasi; IHD: Ischemic Heart Disease; DM: Diabetes Mellitus; MAP : Mean Arterial Pressure; WBC: White Blood Cell 
menyebabkan perbedaan diantara tipe Anthonisen tidak terlihat. Setelah mengeksklusi outlier dengan kadar PCT $>3,2, \mathrm{ng} / \mathrm{ml}$ maka dilakukan analisis uji beda median Kruskal Wallis dan didapatkan adanya perbedaan bermakna median procalcitonin berdasarkan derajat eksaserbasi Anthonisen. Pada tabel 2 terlihat bahwa median PCT lebih tinggi signifikan pada Anthonisen tipe 1 dibanding Anthonisen tipe 2 dan 3 ( $p$ $=0,029$ ).

Tabel 2. Perbandingan median procalcitonin berdasarkan tipe Anthonisen setelah menghilangkan outliers $(\mathrm{n}=36)$

\begin{tabular}{|c|c|c|c|c|}
\hline \multirow[b]{2}{*}{ Variabel } & \multicolumn{3}{|c|}{ Tipe Anthonisen } & \multirow[b]{2}{*}{$\begin{array}{l}\text { Nilai } \\
\text { p }\end{array}$} \\
\hline & $\begin{array}{c}3 \text { gejala } \\
\text { kardinal } \\
\text { /Tipe } 1 \\
(n=12)\end{array}$ & $\begin{array}{c}2 \text { gejala } \\
\text { kardinal } \\
\text { /Tipe } 2 \\
(\mathrm{n}=10)\end{array}$ & $\begin{array}{c}1 \text { gejala } \\
\text { kardinal } \\
\text { /Tipe } 3 \\
\quad(n=14)\end{array}$ & \\
\hline $\begin{array}{l}\text { PCT }(\mathrm{ng} / \mathrm{ml}) ; \\
\text { median }\end{array}$ & 0,34 & 0,11 & 0,14 & \\
\hline (IQR) & $(0,09-2,62)$ & $(0,02-1,11)$ & $(0,06-1,15)$ & 0,029 \\
\hline
\end{tabular}

Untuk mengetahui hubungan antara kadar procalcitonin pada masing-masing gejala kardinal (peningkatan sesak, peningkatan produksi sputum dan purulensi sputum, dan purulensi sputum), maka dilakukan analisis korelasi Spearman. Hasil didapatkan korelasi bermakna antara kadar procalcitonin dengan gejala peningkatan sesak ( $\mathrm{r}$ $=0,329 ; \mathrm{p}=0,031)$ dan tidak berkorelasi dengan peningkatan volume sputum dan purulensi sputum $(\mathrm{p}>0,05)$.

\section{DISKUSI}

Umur seringkali disebutkan sebagai faktor risiko, namun hal ini masih belum jelas apakah terkait kumulatif paparan lingkungan selama hidup. ${ }^{2}$ Tren prevalensi penderita PPOK saat ini, pada laki-laki sama dengan pada perempuan yang kemungkinan disebabkan perubahan pola merokok. ${ }^{2}$ Pada penelitian ini, jumlah penderita laki-laki dan perempuan hampir sama. Pada penelitian ini, faktor risiko merokok didapatkan sebesar 58,1\% penderita. Merokok merupakan faktor risiko PPOK yang paling sering didapatkan. ${ }^{2}$ Pada penelitian ini sebagian besar penderita berisiko tinggi eksaserbasi yang sering (86\%). Eksaserbasi akut yang memerlukan rawat inap berhubungan dengan prognosis yang buruk dan risiko kematian yang meningkat. ${ }^{2}$

Rerata temperatur penderita PPOK eksaserbasi akut pada penelitian ini tidak meningkat yaitu $36,6^{\circ} \mathrm{C}$. Rerata WBC sedikit meningkat pada penelitian ini $\left(13,22 \times 10^{3} / \mathrm{ml} \pm 5,52\right)$ dengan median $12,6 \times 10^{3} / \mathrm{ml}$. Leukositosis, penggunaan otot aksesoris pernafasan, respirasi > $30 \mathrm{kali} /$ menit, nadi $>120 \mathrm{kali} /$ menit dan demam merupakan parameter untuk rekomendasi pemberian antibiotik pada PPOK eksaserbasi akut. ${ }^{8}$

Median procalcitonin penderita PPOK eksaserbasi akut pada penelitian ini $0,18 \mathrm{ng} / \mathrm{ml}(0,02-47,8)$. Studi oleh Stolz $\mathrm{dkk}^{9}$ mendapatkan median $0,088 \mathrm{ng} / \mathrm{ml}(0,053-0,161)$. Pada penelitian ini, 46,5\% mempunyai PCT $\geq 0,25 \mathrm{ng} / \mathrm{ml}$ dan $53,5 \%$ mempunyai PCT $<0,25 \mathrm{ng} / \mathrm{ml}$. Hal ini sesuai dengan bukti-bukti yang ada saat ini bahwa prevalensi infeksi bakteri pada PPOK eksaserbasi akut sekitar $40-50 \% .^{10}$ Studi-studi lain mendapatkan penderita dengan PCT $\geq 0,25 \mathrm{ng}$-ml berkisar antara 17,2\%-45\%.,11,12 Infeksi virus merupakan diagnosis diferensial yang pertama pada pasien sakit akut jika kadar PCT $<0,1 \mathrm{ng} / \mathrm{mL}$. Pada infeksi bakteri yang terlokalisir, rentang kadar PCT mulai dari 0,25 sampai $1 \mathrm{ng} / \mathrm{ml}$. Kadar PCT yang rendah juga bisa disebabkan infeksi yang dini sehingga dapat dilakukan pemantauan kadar PCT Jika kadar PCT $>1 \mathrm{ng} / \mathrm{ml}$, klinisi sebaiknya mempertimbangkan infeksi bakteri sistemik yang lebih berat. ${ }^{6}$ Tingginya kadar procalcitonin pada PPOK eksaserbasi akut relatif spesifik untuk kondisi penyakit yang lebih berat seperti pneumonia.'

Pada studi ini hanya sebagian kecil yang dilakukan pemeriksaan mikrobiologi kultur sputum dan kultur darah. Dari hasil kultur darah dan sputum, tidak didapatkan pertumbuhan kuman dan hanya ditemukan flora normal regional. Hal ini sesuai mengingat prevalensi bakteri di saluran nafas bawah sulit ditentukan disebabkan sulitnya mendapatkan sampel yang tidak terkontaminasi oleh flora normal dari sekret saluran nafas atas. ${ }^{13}$

Pada penelitian ini tidak didapatkan hubungan yang bermakna antara kadar procalcitonin dengan tipe Anthonisen $(\mathrm{r}=-0,175 ; \mathrm{p}=0,26)$. Hal ini mungkin disebabkan adanya outliers yang sangat berpengaruh pada hasil uji korelasi. Studi oleh Valk dkk ${ }^{14}$ mendapatkan bahwa gejala klasik Anthonisen tipe 1 (sesak, volume sputum dan purulensi sputum) bukan merupakan prediktor penyebab bakteri pada eksaserbasi PPOK. Hasil penelitian ini juga sesuai dengan penelitian oleh Stolz $\mathrm{dkk}^{9}$ yang mendapatkan bahwa PCT tidak berkorelasi dengan tipe Anthonisen. Lacoma dkk ${ }^{15}$ juga tidak mendapatkan perbedaan kadar procalcitonin berdasarkan kriteria Anthonisen. Falsey dkk ${ }^{16}$ mendapatkan anthonisen tipe 1 yang tidak berbeda antara kelompok dengan kadar PCT $<0,25 \mathrm{ng} / \mathrm{ml}$ dengan kelompok dengan kadar PCT $\geq 0,25 \mathrm{ng} /$ $\mathrm{ml}$.

Pada penelitian ini, setelah menghilangkan beberapa outlier dengan kadar PCT $>3,2 \mathrm{ng} / \mathrm{ml}$, dilakukan uji beda median dengan metode Kruskal wallis kadar PCT pada masing-masing tipe Anthonisen. Berbeda dengan studi oleh Stolz $\mathrm{dkk}^{9}$ yang tidak mendapatkan perbedaan median kadar procalcitonin diantara tipe Anthonisen maupun derajat GOLD, pada penelitian ini didapatkan perbedaan yang signifikan kadar PCT berdasarkan tipe Anthonisen, dimana median 
PCT Anthonisen tipe 1 lebih tinggi bermakna dibandingkan median PCT tipe 2 dan 3. Hal ini mengindikasikan bahwa kemungkinan infeksi bakteri pada Anthonisen tipe 1 lebih kuat dibandingkan tipe 2 dan 3, sehingga pada PPOK derajat berat (Anthonisen tipe 1) mendukung untuk diberikan antibiotik. Hal ini sesuai dengan rekomendasi pedoman tatalaksana PPOK oleh GOLD bahwa antibiotik diberikan pada PPOK eksaserbasi berat berdasar kriteria Anthonisen. Penelitian lain juga mendapatkan kadar procalcitonin lebih tinggi bermakna pada Anthonisen tipe 1 dibanding tipe 2 dan 3 (PCT 0,33 ng/ $\mathrm{ml}$ versus $0,08 \mathrm{ng} / \mathrm{ml}$ dan $0,05 \mathrm{ng} / \mathrm{ml}, \mathrm{p}<0,0001) .{ }^{17}$

Jika berdasarkan titik potong kadar PCT 0,25 ng/ml, 64,3\% penderita Anthonisen tipe 1 disarankan pemberian antibiotika (algoritma berbasis PCT). Proporsi ini lebih tinggi dibandingkan penderita Anthonisen tipe 2 dan 3 yang hanya $25 \%$ dan 47,1\%. Jika dibedakan berdasar nilai titik potong kadar PCT $0,5 \mathrm{ng} / \mathrm{ml}$, dimana kadar $\geq 0,5 \mathrm{ng} /$ $\mathrm{ml}$ sangat disarankan untuk pemberian antibiotik, maka pada penelitian ini, sebagian besar kelompok penderita dengan gejala Anthonisen tipe 2 dan 3 tidak disarankan mendapat antibiotik (75-76,5\%), sedangkan kelompok penderita dengan gejala Anthonisen tipe 1, hampir setengahnya sangat disarankan pemberian antibiotik $(42,9 \%)$. Kadar procalcitonin $<0,5 \mathrm{ng} / \mathrm{ml}$ menunjukkan kemungkinan infeksi lokal, sedangkan kadar $\geq 0,5 \mathrm{ng} / \mathrm{ml}$ menunjukkan kemungkinan infeksi bakteri sistemik. ${ }^{18}$ Data ini menunjukkan bahwa pada penderita PPOK eksaserbasi derajat berat (Anthonisen tipe 1), lebih sering disebabkan oleh infeksi bakteri dan lebih banyak memerlukan antibiotik dibandingkan derajat sedang dan ringan (Anthonisen tipe 2 dan 3 ).

Penelitian ini juga mendapatkan korelasi yang bermakna antara tipe Anthonisen dengan kadar WBC ( $\mathrm{r}=$ $0,412, p=0,006)$, dan hitung neutrofil $(r=-0,403, p=0,007)$ namun tidak menemukan korelasi antara purulensi sputum dengan WBC dan hitung neutrofil ( $p>0,05$ ). Hal ini berarti pada derajat eksaserbasi yang berat berhubungan dengan peningkatan WBC dan hitung neutrofil yang merupakan marker inflamasi sistemik. WBC meningkat sebagai respon terhadap infeksi dan inflamasi. Hitung jenis neutrofil juga meningkat pada kondisi inflamasi dan berguna melawan patogen dengan cara melepaskan substansi toksik dan enzim degradasi. ${ }^{19}$ Berbeda dengan PCT, WBC merupakan marker inflamasi yang non spesifik. Pada tempat dimana PCT tidak tersedia, WBC dan hitung neutrofil yang meningkat masih bisa dipakai sebagai data pendukung adanya infeksi bakteri pada PPOK eksaserbasi akut yang mudah dan lebih murah.

Meskipun tidak didapatkan korelasi yang bermakna antara kadar procalcitonin dengan kriteria Anthonisen, namun kami mendapatkan perbedaan yang signifikan median PCT berdasarkan tipe Anthonisen dimana pada derajat eksaserbasi berat (Anthonisen tipe 1) median PCT lebih tinggi signifikan dibanding derajat sedang dan ringan (Anthonisen tipe 2 dan 3). Jadi pada eksaserbasi berat kemungkinan infeksi bakteri lebih besar dibanding derajat ringan dan sedang, sehingga kriteria Anthonisen mungkin masih berguna dalam menentukan pemberian antibiotika pada PPOK eksaserbasi akut terutama jika pemeriksaan PCT tidak bisa dilakukan.

\section{SIMPULAN}

Berdasarkan hasil yang ditemukan pada penelitian ini, dapat disimpulkan bahwa tidak terdapat hubungan antara kadar procalcitonin dengan derajat keparahan eksaserbasi berdasarkan tipe Anthonisen pada penderita PPOK eksaserbasi akut.

Meskipun demikian, kadar procalcitonin lebih tinggi bermakna pada PPOK eksaserbasi Anthonisen tipe 1 dibandingkan tipe 2 dan 3. Proporsi yang disarankan mendapat antibiotik berdasarkan algoritme PCT juga lebih besar pada penderita PPOK eksaserbasi Anthonisen tipe 1 dibandingkan tipe 2 dan 3.

\section{DAFTAR PUSTAKA}

1. Robbins RA. COPD exacerbation: an evidence-based review. Southwest $J$ Pulm Crit Care. 2012;5:36-51

2. Decramer M, Agusti AG, Bourbeau J, dkk. Global strategy for the diagnosis, management, and prevention of chronic obstructive pulmonary disease update 2016. Global Initiative for Chronic Obstructive Pulmonary Disease Inc [serial online] 2016 [diakses 20 Juni 2016]. Diunduh dari: http://goldcopd.org/global-strategy-diagnosismanagement-prevention-copd-2016/

3. Halpin DM, Decramer M, Celli B, dkk. Exacerbation frequency and course of COPD. Int J Chron Obstruct Pulmon Dis. 2012; 7:653-61

4. Soler N, Agusti C, Angrill, J, dkk. Bronchoscopic validation of the significance of sputum purulence in severe exacerbation of chronic obstructive pulmonary disease. Thorax. 2007;62:29-35

5. Schuetz P, Albrich, W, Mueller B. Procalcitonin for diagnosis of infection and guide to antibiotic decisions: past, present and future. BMC Med. 2011;9(107):1-9

6. Foushee JA, Hope N, Grace EE. Applying biomarkers to clinical practice: a guide for utilizing procalcitonin assays. J Antimicrob Chemother. 2012; 67(11):2560-2569

7. Li H, Luo YF, Blackwell TS, dkk. Meta analysis and systematic review of procalcitonin-guided therapy in respiratory tract infections. Antimicrob Agents Chemoter. 2011; 55(12):5900-5906

8. Laue J, Reierth E, Melbye H. When should acute exacerbations of COPD be treated with systemic corticosteroids and antibiotics in primary care: a systemic review of current COPD guidelines. NPJ Rim Care Respir Med. $2015 ; 25: 1-6$

9. Stolz D, Christ-crain M, Morgenthaler NG, dkk. Copeptin, C-reactive protein, and procalcitonin as a prognostic biomarkers in acute exacerbation of COPD. Chest. 2007; 131:1058-1067

10. Sethi S. Bacteria in exacerbations of chronic obstructive pulmonary disease, phenomenon or epiphenomenon. Proc Am Thorax Soc. 2004; 1(2):109-114

11. Christ-crain M, Stolz DJ, Bingisser R, dkk. Effect of procalcitoninguided treatment on antibiotic use and outcome in lower respiratory tract infections: cluster-randomised, single-blinded intervention trial. Lancet. 2004; 363:600-07

12. Burke L, Alhajji M, Todd N, dkk. Procalcitonin (PCT) is a safe and reliable biomarker of bacterial infection in exacerbation of COPD-so why is it so challenging to introduce it into a large UK hospital?. Thorax 


\section{ARTIKEL ASLI}

Jurnal Penyakit Dalam Udayana

Udayana Journal of Internal Medicine

Volume 3, No 1: 2019

Print ISSN: 2580-2925

Online ISSN: $2580-2933$

\section{0; 65:A125-A126}

13. Beasley V, Joshi PV, Singanayagam A, dkk. Lung microbiology and exacerbation in COPD. Int JChron Obstruct Pulmon Dis. 2012; 7:555-569

14. Valk PV, Monninkhof E, Palen JV, dkk. Clinical predictors of bacterial involvement in exacerbations of chronic obstructive pulmonary disease. Clin Infect Dis. 2004; 39:980-6

15. Lacoma, A, Prat C, Andreo F, dkk. Biomarkers in the management of COPD. Eur Respir Rev. 2009; 18(112):96-104.

16. Falsey AR, Becker KL, Swinburne AJ, dkk. Utility of serum procalcitonin values in patients with acute exacerbations of chronic obstructive pulmonary disease: a cautionary note. Int J Chron Obstruct Pulmon Dis. 2012; 7:127-135

17. Pazarli AC, Koseoglu HI, Doruk S, dkk. Procalcitonin: is it a predictor of noninvasive positive pressure ventilation necessity in acute chronic obstructive pulmonary disease exacerbation?. J Res Med Sci. 2012;17(11):1047-1051
18. Chaudhury A, Sumant GLS, Jayaprada R, dkk. Procalcitonin in sepsis and bacterial infections. JClin Sci Res. 2013;2:216-24

19. Chmielewski PP, Strzelec B. Elevated leukocyte count as a harbinger of systemic inflammation, disease progression, and poor prognosis: a review. Folia Morphol.2018;77(2):171-178

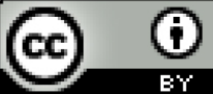

This work is licensed under a Creative Commons Attribution 4.0 International License. 